\title{
DETEKSI ADULTERAN DALAM SEDIAAN JAMU TEMU HITAM (Curcuma aeruginosa Roxb.) MENGGUNAKAN METODE ANALISIS SIDIK JARI KLT VIDEO DENSITOMETRI
}

\section{FINGERPRINT ANALYSIS IN DETECTING ADULTERANT IN JAMU TEMU HITAM (Curcuma aeruginosa Roxb.) USING TLC VIDEO DENSITOMETRY}

\author{
Emma Emawati ${ }^{1}$ Yesinta $^{1}$, Anan Niazi Usman ${ }^{2}$, Aiyi Asnawi ${ }^{3}$ \\ ${ }^{1}$ Sekolah Tinggi Farmasi Bandung, Jl. Soekarno Hatta No. 754 Cibiru, \\ Bandung, Jawa Barat, 40161, Indonesia \\ ${ }^{2} J u r u s a n$ Teknik Informatika, Fakultas Teknik, Universitas Jabal Ghafur, \\ Sigli, Aceh, 24171, Indonesia \\ ${ }^{3}$ School of Pharmacy, Bandung Institute of Technology, \\ Bandung, West Java, 40132, Indonesia \\ Email: aiyiasnawi@fa.itb.ac.id (Aiyi Asnawi)
}

\begin{abstract}
ABSTRAK
Temu hitam (Curcuma aeruginosa Roxb.) merupakan salah satu jenis temu-temuan dari suku Zingiberacea, memiliki khasiat antara lain sebagai penambah nafsu makan, membersihkan setelah melahirkan, mengobati batuk berdahak, sesak nafas, dan penyakit kulit. Banyaknya khasiat dari temu hitam menyebabkan temu hitam sering dikonsumsi dalam bentuk sediaan jamu instan. Namun kurangnya kontrol kualitas standar dari obat herbal mengakibatkan banyaknya kecurangan dalam pembuatan sediaan jamu. Kromatografi sidik jari dengan KLT video densitometri dapat memberikan informasi mengenai integritas, kesamaan, dan perbedaan komponen kimia dalam ekstrak atau produk herbal yang diteliti dengan cepat dan mudah. Tujuan dari penelitian ini adalah untuk mengembangkan metode Kromatografi Lapis Tipis (KLT) video densitometri sidik jari dan analisis PCA (Principal Component Analysis) untuk menguji keaslian sediaan jamu temu hitam. Determinasi ekstrak dan sediaan jamu temu hitam dilakukan menggunakan metode KLT video densitometri yang tervalidasi dengan komposisi fasa gerak adalah campuran $n$-heksana : etil asetat $(3: 1,5 ; \mathrm{v} / \mathrm{v})$ dan silika gel $60 \mathrm{GF}_{254}$ sebagai fasa diam. Adulteran yang digunakan adalah kunyit (Curcuma longa). Pendeteksian menggunakan pereaksi anisaldehida sedangkan perekaman bercak menggunakan kamera mirrorless dan bercak ditransformasi menggunakan perangkat lunak TLC analyzer. Analisis PCA menggunakan metode kemometrik menghasilkan data berupa score dan loading. Terdapat pola data PCA dari ekstrak temu hitam terhadap kunyit dalam kelompok masing-masing. Hasil dari ketiga produk temu hitam instan yang diuji menunjukkan bahwa dua produk tidak mengandung adulteran kunyit karena memiliki karakteristik yang sama dengan temu hitam dan satu produk tidak mengandung temu hitam dan kunyit. Profil KLT video densitometri sidik jari dipetakan dengan PCA menggunakan variabel $\mathrm{Rf}$ telah berhasil mengidentifikasi keaslian sediaan bubuk temu hitam murni terhadap adulterasi dengan kunyit.
\end{abstract}


Kata kunci: aduterasi, jamu, kunyit, sidik jari KLT, PCA, temu hitam, video densitometri.

\begin{abstract}
Temu hitam (Curcuma aeruginosa Roxb.) is a member of Zingiberaceae (ginger) family with health benefits includes increasing appetite, cleansing after childbirth, and curing coughing with phlegm, dispnea, and skin diseases. Temu hitam is commonly consumed in the form of instant jamu preparation. However, lack of quality control of herbal drugs production leads to many frauds in producing the jamu temu hitam. Fingerprint chromatography using TLC video densitometry can provide information on integrity, similarities, and differences of chemical components in herbal extracts or products quickly and easily. The purpose of this study was detecting adulterant (turmeric) qualitatively in jamu temu hitam using fingerprint analysis by TLC video densitometry. The fingerprint TLC patterns were recorded after separation using silica gel $\mathrm{GF}_{254} \mathrm{~nm}$ as stationary phase, and mixture of $n$-hexane: ethyl acetate $(3: 1.5, v / v)$ as mobile phase. Spot detection and recording were conducted using mirrorless camera after derivatization with anisaldehyde reagent and under UV lights at $254 \mathrm{~nm}$ and $365 \mathrm{~nm}$. The spot was transformed by TLC analyzer software. Chemometric method with principal component analysis (PCA) was used to produce score and loading. The grouping data of both turmeric and temu hitam was used to analyze adulterant in instant jamu products. Of the three tested: jamu temu hitam products, two products contained no turmeric adulterant because it had the same characteristics as those of temu hitam and one product did not contain both temu hitam as well as turmeric. The last product was suspected to contain other adulterants. The profile of fingerprint from TLC video densitometry could be used to differentiate the characteristics of temu hitam and turmeric and hence was useful for spotting adulterants in jamu temu hitam.
\end{abstract}

Key words: adulterant, jamu, turmeric, fingerprint TLC, Principal Component Analysis $(P C A)$, temu hitam, video densitometry. 


\section{Pendahuluan}

Keanekaragaman

hayati

Indonesia merupakan salah satu yang terbesar di dunia. Namun, pemanfaatannya masih sangat rendah terutama dalam bidang obat dan makanan. Di samping itu, dengan sebaran pulau yang sangat banyak berakibat pada keberagaman terhadap komposisi kimia dari varietas yang sama, seperti kopi. Kopi dengan varieritas yang sejenis namun tumbuh di daerah yang berbeda maka akan mempunyai kualitas dan kandungan kimia yang khas. Salah satu pemanfaatan keragaman hayati oleh penduduk Indonesia adalah pemanfaatan tumbuhan sebagai obat yang dikenal dengan jamu. Obat tradisional Indonesia atau jamu mengandung satu tanaman obat tunggal atau campuran tanaman herbal, dan digunakan untuk pencegahan atau pengobatan penyakit, termasuk penyakit yang diwariskan secara genetis dari generasi ke generasi. Salah satu tanaman herbal yang sering digunakan adalah Curcuma aeruginosa Roxb. (Zingiberaceae), yang dikenal dengan nama "Temu hitam" (Dalimartha, 2007). Temu hitam telah diuji memiliki aktifitas antara lain sebagai anti-inflamasi (Reanmongkol et al., 2006), mengobati penyakit kulit (Djauharia dan Sufiani, 2007), batuk dan asma (Nasrullah et al., 2010), antimikroba (Angel et al., 2012), antioksidan (Nurcholis et al., 2015), dan anticendawan (Srivastava et al., 2006).

Adulterasi (penambahan atau penggantian bahan) pada sediaan farmasi terutama jamu sering ditemui, misalnya kunyit ditambahkan dengan jagung untuk menaikkan bobot massa produk. Biasanya bahan (adulteran) yang digunakan memiliki nilai ekonomis lebih rendah dari bahan utamanya. Oleh karenanya, pendeteksian kemungkinan adanya adulteran dalam sediaan herbal sangat penting untuk melindungi konsumen dan kesehatan masyarakat. Akibatnya, metode analisis yang cepat untuk pendeteksian adulteran sangat diperlukan.

Beragam metode telah dikembangkan untuk menguji keaslian sediaan farmasi, seperti Kromatografi Lapis Tipis (KLT) (Pothitirat and Gritsanapan, 2005), KLT kinerja tinggi (Ashraf et al., 2012), kromatografi cair kinerja tinggi (Jayaprakasha et al., 2002), dan spektroskopi infra merah (Rohman et al., 2015). Metode KLT memiliki banyak kelebihan di antaranya preparasi yang sederhana, sedikit menggunakan pelarut organik, dapat digunakan untuk 
analisis kualitatif dan semikuantitatif, mampu menganalisis sampel secara serentak, dan hemat waktu dan biaya. Analisis image telah ditandemkan dengan metode KLT misalnya dalam penetapan kadar pseudoefedrin $\mathrm{HCl}$ dan loratadin (Asnawi et al., 2017) dan analisis sidik jari adulteran pada sediaan bubuk kunyit (Muttaqin et al., 2018). Tujuan penelitian ini adalah mendeteksi adulteran dalam sediaan jamu temu hitam menggunakan metode sidik jari dalam KLT video densitometri. Metode KLT video densitometri digunakan dikarenakan lebih sederhana, murah, dan dapat dikembangkan secara mandiri untuk keperluan komersial serta dapat dijadikan alternatif instrumen analisis menggantikan KLT pemindaian densitometri. Dalam kajian ini, profil kromatogram sidik jari digabungkan dengan metode Principal Component Analysis (PCA) kemometrik untuk menguji kemurnian sediaan jamu temu hitam.

\section{Metode Penelitian}

Bahan

Rimpang temu hitam (Curcuma aeruginosa Roxb.) diperoleh dari Lampung, Jawa Barat, dan Jawa Tengah, Indonesia pada Desember 2017 dan dilakukan determinasi pada Laboratorium Taksonomi Tumbuhan, Jurusan Biologi, Fakultas Matematika dan Ilmu Pengetahuan Alam, Universitas Padjajaran, Jatinangor, Jawa Barat.

Instrumentasi

Pola bercak KLT sidik jari dilakukan menggunakan sistem semiautomatis TLC sampler Linomat V (terhubung dengan tabung nitrogen), twin-through chamber. Gambar bercak pada plat KLT direkam menggunakan kamera Sony Alpha A5100. Kromatogram dari bercak pada plat KLT ditranformasi menggunakan perangkat lunak TLC Analyzer (Hess, 2007).

Jalannya Penelitian

1. Penyiapan ekstrak temu hitam

Simplisia rimpang temu hitam diekstraksi dengan metode maserasi menggunakan pelarut etanol $96 \%$. Sebanyak 150 gram serbuk kering rimpang temu hitam dimasukan ke dalam maserator kemudian ditambahkan $500 \mathrm{~mL}$ etanol 96\% dan direndam selama 24 jam sambil sesekali diaduk. Maserat dipisahkan dan dipindahkan ke erlenmeyer lain, sedangkan ampas dimaserasi kembali dengan pelarut etanol $96 \%$ segar sebanyak 2 kali. Maserat yang diperoleh disaring dan dipekatkan 
menggunakan alat vakum uap putar pada suhu $30-40{ }^{\circ} \mathrm{C}$ sampai diperoleh ekstrak kental. Ekstrak dilarutkan dalam etanol sampai diperoleh konsentrasi $2 \%$ untuk dilakukan analisis sidik jari.

2. Penyiapan ekstrak kunyit

Simplisia rimpang kunyit diekstraksi dengan metode maserasi menggunakan pelarut etanol $96 \%$. Sebanyak 150 gram serbuk kering rimpang kunyit dimasukan ke dalam maserator kemudian ditambahkan $500 \mathrm{~mL}$ etanol $96 \%$ dan direndam selama 24 jam sambil sesekali diaduk. Maserat dipisahkan dan dipindahkan ke erlenmeyer lain, sedangkan ampas dimaserasi kembali dengan pelarut etanol 96\% segar sebanyak 2 kali. Maserat yang diperoleh disaring dan dipekatkan menggunakan alat vakum uap putar pada suhu $30-40{ }^{\circ} \mathrm{C}$ sampai diperoleh ekstrak kental. Ekstrak dilarutkan dalam etanol sampai diperoleh konsentrasi $2 \%$ untuk dilakukan analisis sidik jari.

3. Analisis KLT sidik jari

Sebanyak $60 \mathrm{~mL}$ ekstrak etanol dari temu hitam dan kunyit ditotolkan pada plat silika gel $60 \quad \mathrm{GF}_{254}$ menggunakan semiautomatic sampler CAMAG Linomat V. Kemudian, plat
KLT dikembangkan menggunakan fase gerak campuran $n$-heksana : etil asetat $(3: 1,5 ; \mathrm{v} / \mathrm{v})$ pada suhu dan kelembaban ruang. Setelah dielusi, plat dikeringkan dan direkam gambarnya setelah digunakan penampak bercak vanilin-asam sulfat.

4. Penyiapan ekstrak sampel jamu temu hitam

Sampel jamu temu hitam diekstraksi dengan metode maserasi menggunakan pelarut etanol $96 \%$. Sebanyak 150 gram serbuk kering rimpang temu hitam dimasukan ke dalam maserator kemudian ditambahkan $500 \mathrm{~mL}$ etanol $96 \%$ dan direndam selama 24 jam sambil sesekali diaduk. Maserat dipisahkan dan dipindahkan ke erlenmeyer lain, sedangkan ampas dimaserasi kembali dengan pelarut etanol $96 \%$ segar sebanyak 2 kali. Maserat yang diperoleh disaring dan dipekatkan menggunakan alat vakum uap putar pada suhu $30-40{ }^{\circ} \mathrm{C}$ sampai diperoleh ekstrak kental. Ekstrak sampel jamu temu hitam dilarutkan dalam etanol sampai diperoleh konsentrasi $2 \%$ untuk dilakukan analisis KLT sidik jari dimana tahapannya sesuai dengan yang dilakukan pada ekstrak temu hitam. Klasifikasi kualitas sampel 


dilakukan dengan menentukan
karakteristik puncak kromatogram
menggunakan metode PCA
kemometrik.

\section{Analisis statistika}

Data pengamatan diukur dengan tiga kali pengulangan. Analisis statistika perhitungan PCA dilakukan menggunakan perangkat lunak Unscrambler ${ }^{\circledR} \mathrm{X}$ versi trial.

\section{Hasil dan Pembahasan}

Produk tanaman dan obat herbal yang tersedia secara komersial rentan terhadap substitusi atau kontaminasi dengan bahan lain yang tidak berlabel atau tidak diinginkan. Hal ini akan mengurangi kualitas produk, dan dapat menyebabkan keracunan dan alergi. KLT video densitometri sidik jari merupakan metode yang memungkinkan mengidentifikasi bahan tanaman dengan menggunakan profil $\mathrm{Rf}$ dari kromatogram melalui transformasi analisis gambar dengan cara yang mudah, cepat, akurat, dan hemat biaya. Sebanyak sembilan sampel dianalisis mencakup tiga sampel temu hitam segar, tiga sampel adulteran kunyit segar, dan tiga sampel sediaan jamu temu hitam. Sebanyak $150 \mathrm{~g}$ simplisia kering (temu hitam, kunyit, dan sampel) diekstraksi dengan pelarut etanol 96\% dan diperoleh ekstrak kental dengan rendemen sekitar 13,20\%. Ekstrak yang diperoleh selanjutnya dibuatkan pola kromatogram menggunakan plat KLT silika gel.

Pola bercak KLT sidik jari dapat dinyatakan sebagai profil senyawa kimia yang terkandung dalam suatu ekstrak dan dapat ditransformasikan ke dalam bentuk kromatogram. Berbagai perangkat lunak baik yang gratis maupun berbayar dapat digunakan untuk mentransformasikan gambar pola bercak KLT menjadi kromatogram. Pada penelitian ini digunakan perangkat lunak TLC Analyzer (Hess, 2007) dikarenakan gratis dan hasilnya juga sangat memuaskan. Pola bercak KLT temu hitam menunjukkan $\mathrm{Rf}$ khusus untuk setiap sampel (Gambar 1). Terdapat beberapa perbedaan pada rentang $\mathrm{Rf}$ tertentu. Temu hitam dari Lampung (tl) dan Jawa Tengah (tjt) mempunyai bercak khas di sekitar Rf 0,34 tetapi noda ini tidak kelihatan jelas pada temu hitam dari Jawa Barat (tjb). Tetapi tjb mempunyai noda khas di sekitar Rf 0,12 dimana juga ditemukan noda ini pada tjt sedangkan pada tl tidak kelihatan noda ini (Gambar 1a). Perbedaan ini menunjukkan adanya kandungan 
metabolit temu hitam yang berbeda dikarenakan perbedaan tempat tumbuhnya. Rentang Rf 0,3-3; 3-6; dan 6-10 biasanya menunjukan adanya senyawa golongan minyak esensial/asam lemak, karbohidrat, dan aromatis (Booker et al., 2014).

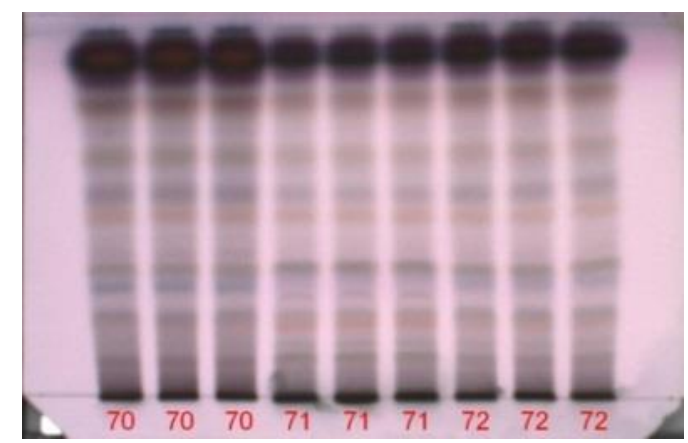

(a)

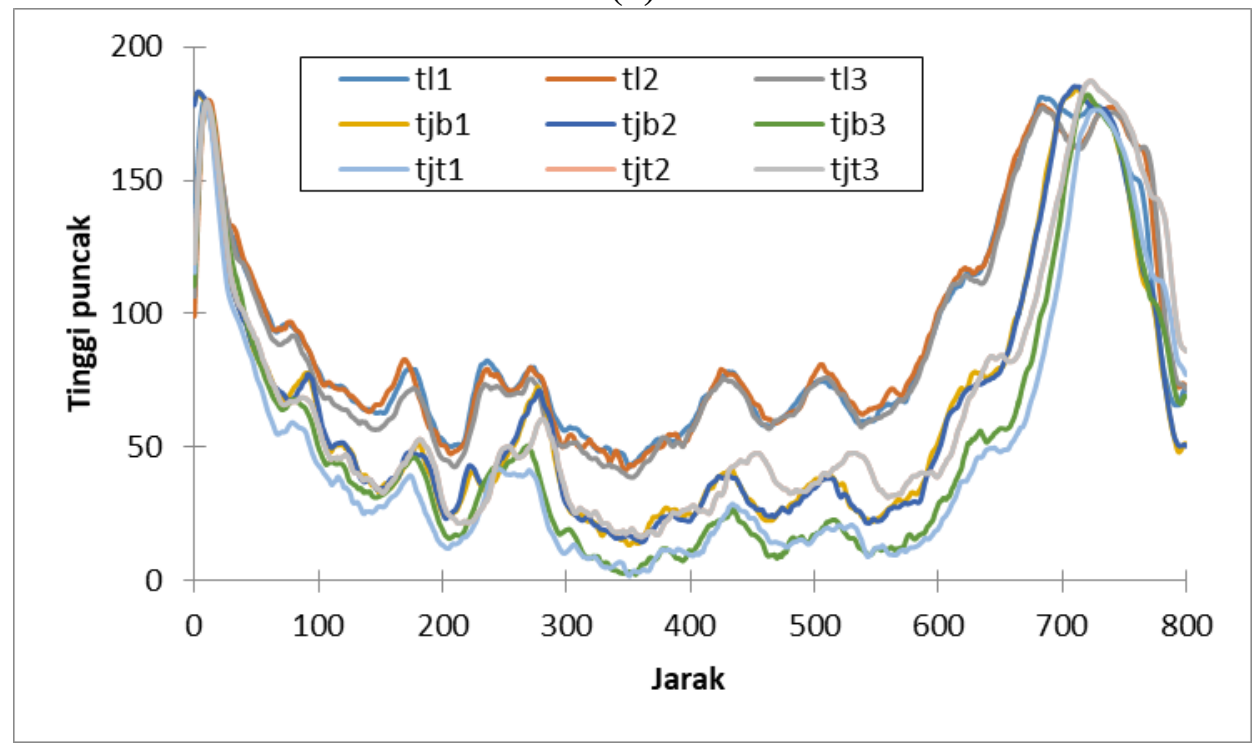

(b)

Gambar 1. Pola KLT ekstrak temu hitam dari Lampung (70: t|1, t|2, t|3), Jawa Barat (71: tjb1, tjb2, tjb3), dan Jawa Tengah (72: tjt1, tjt2, tjt3) dengan perekaman gambar di bawah penampak bercak anisaldehida (a) dan kromatogram transformasi gambar plat KLT dari ekstrak temu hitam dari tranformasi (b). Silika gel $\mathrm{GF}_{254} \mathrm{~nm}$ sebagai fase diam dan kombinasi $n$-heksana : etil asetat $(3: 1,5 ; \mathrm{v} / \mathrm{v})$ sebagai fase gerak serta volume penotolan $20 \mu \mathrm{L}$. 
Pola bercak KLT kunyit sebagai adulteran tidak ditemukan noda khas dari berbagai asal tempat tumbuh kecuali intensitas noda lebih tinggi pada noda paling depan dari ekstrak kunyit Jawa Tengah (kjt) (Gambar 2a). Terdapat beberapa perbedaan di kisaran $\mathrm{Rf}$ tertentu. Perbedaan ini disebabkan oleh kandungan metabolit kunyit yang berbeda dikarenakan perbedaan tempat tumbuhnya.

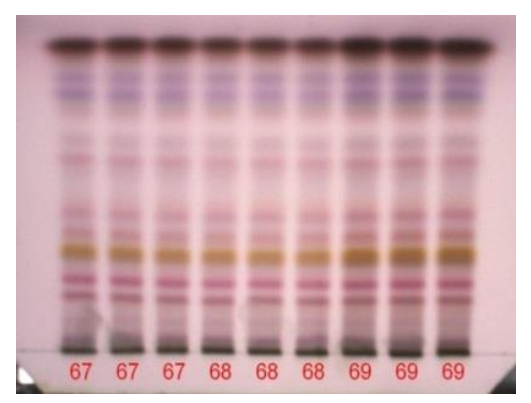

(a)

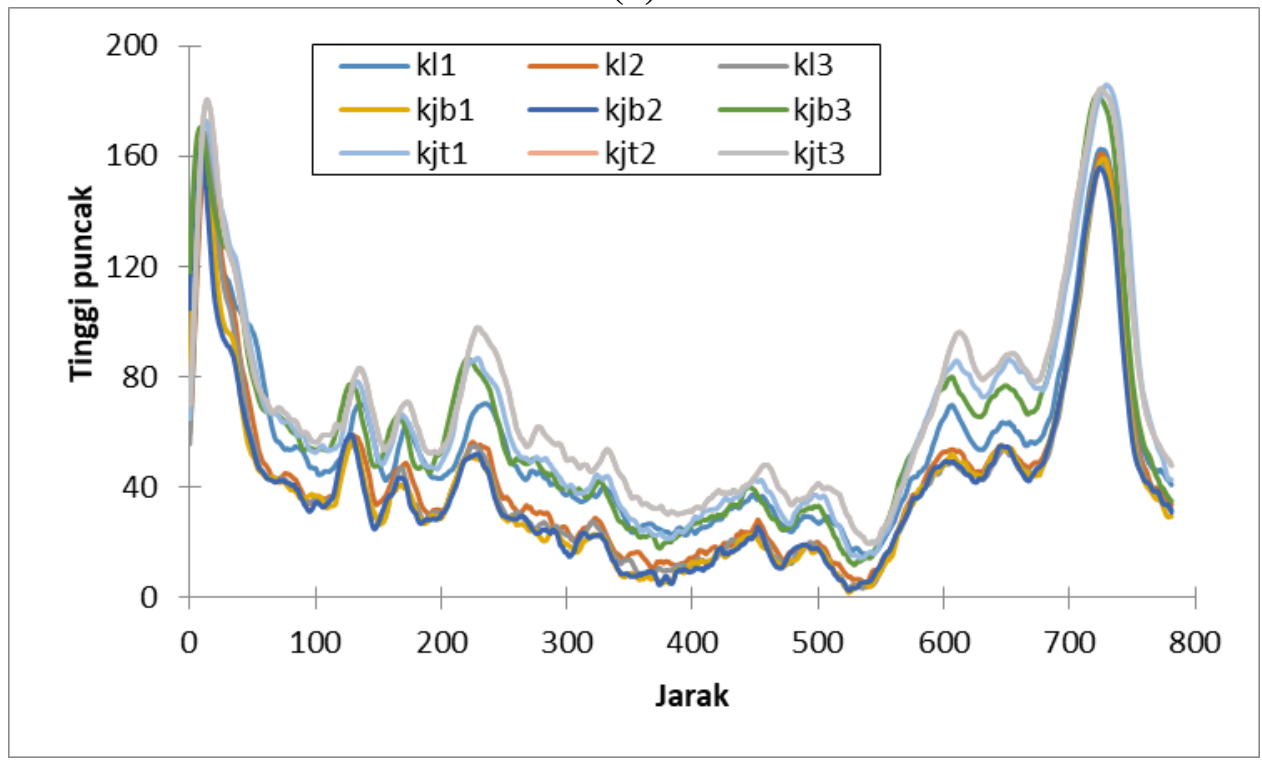

(b)

Gambar 2. Pola KLT ekstrak kunyit dari Lampung (70: kl1, kl2, kl3), Jawa Barat (71: kjb1, kjb2, kjb3), dan Jawa Tengah (72: kjt1, kjt2, kjt3) dengan perekaman gambar di bawah penampak bercak anisaldehida (a) dan kromatogram transformasi gambar plat KLT dari ekstrak kunyit dari tranformasi (b). Silika gel $\mathrm{GF}_{254} \mathrm{~nm}$ sebagai fase diam dan kombinasi $n$-heksana : etil asetat $(3: 1,5 ; \mathrm{v} / \mathrm{v})$ sebagai fase gerak dengan volume penotolan $20 \mu \mathrm{L}$. 
Sampel jamu temu hitam diperoleh dari jamu yang beredar di pasar baik dari toko obat maupun pasar tradisional. Pola bercak KLT dan profil kromatogram dari ketiga sampel uji (Gambar 3) menunjukkan pola berbeda. Sampel pertama (sa1, sa2, dan sa3) dan sampel kedua (sb1, sb2, dan sb3) memiliki kemiripan pola bercak dengan ekstrak temu hitam dan kunyit, sedangkan sampel ketiga (sc1, sc2, dan sc3) hanya memiliki satu noda di sekitar titik penotolan awal. Sampel kedua memiliki noda khas yang lebih kuat pada rentang $\mathrm{Rf} 0-0,8$. Terlihat ada perbedaan pola bercak KLT dan profil kromatogram yang signifikan pada sampel ketiga. Kemungkinan sampel ketiga mengandung golongan senyawa yang sangat polar atau senyawa yang bersifat basa.

Analisis kemometrik multivariat merupakan metode statistik yang dapat mengelola data kompleks yang dihasilkan dari kromatogram. Data ini sangat berguna dalam analisis sidik jari metabolit. Analisis komponen utama (PCA) adalah salah satu analisis multivariat yang dapat digunakan untuk mengklasifikasikan dan membedakan di antara sekelompok sampel tanpa mengetahui tentang keanggotaannya. PCA dapat digunakan untuk membedakan antara temu hitam murni dan kunyit murni. Plot skor temu hitam murni dan kunyit murni muncul di daerah yang berbeda (Gambar 3).

Kemudian dilakukan validasi metode PCA dari baku temu hitam dan kunyit dengan menggunakan metode cross validation. PCA mampu membedakan antara ekstrak baku temu hitam murni dan baku ekstrak kunyit murni (Gambar 4) dengan nilai score PC1 dan PC-2 berturut-turut adalah 71\% dan $16 \%$. Baku temu hitam membentuk klaster tersendiri (lingkaran warna magenta) yang terpisah dari klaster kunyit (lingkaran warna hijau). Secara lebih detail, temu hitam membentuk dua klaster yaitu klaster temu hitam dari Jawa Barat (tjb) dan Jawa Tengah (tjt) dan klaster temu dari Lampung (tl). Hal ini menunjukkan letak geografi dari temu hitam memiliki perbedaan kandungan senyawa kimia (Simoh dan Zainal, 2015). Sedangkan untuk baku kunyit, tidak adanya klasterifikasi yang signifikan dari perbedaan lokasi tumbuhnya. 


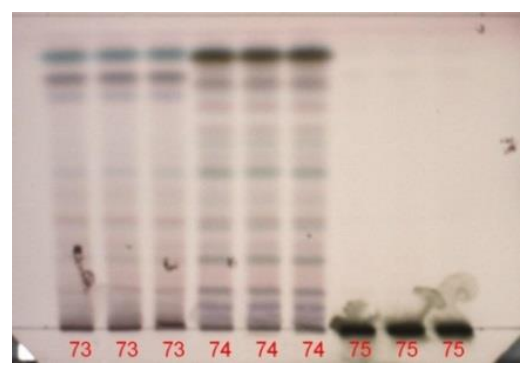

(a)

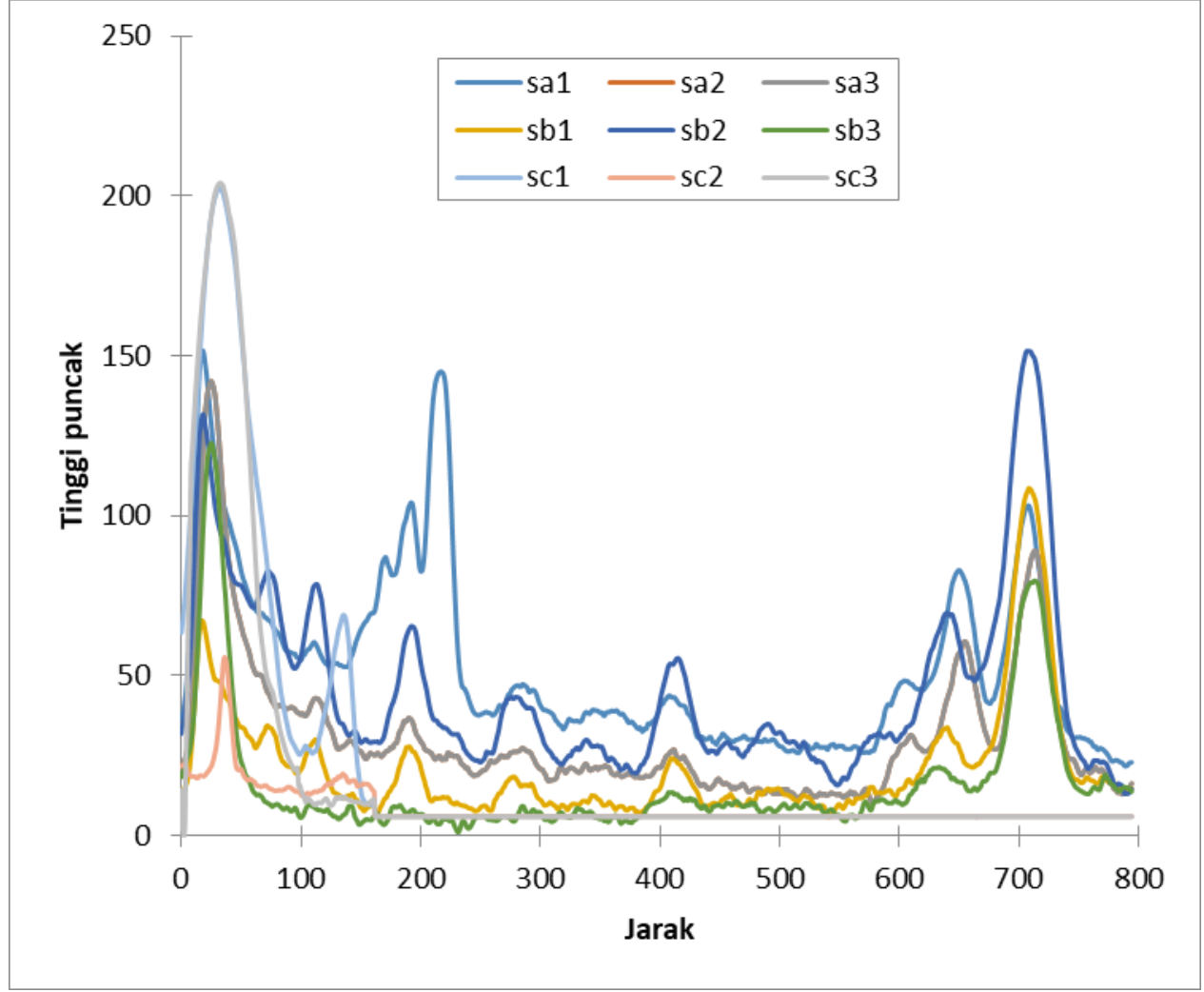

(b)

Gambar 3. Pola KLT sampel jamu temu hitam dari Lampung (73: sa1, sa2, sa3), Jawa Barat (74: sb1, sb2, sb3), dan Jawa Tengah (75: sc1, sc2, sc3) dengan perekaman gambar di bawah penampak bercak anisaldehida (a) dan kromatogram transformasi gambar plat KLT dari ekstrak kunyit dari tranformasi (b). Silika gel $\mathrm{GF}_{254} \mathrm{~nm}$ sebagai fase diam dan kombinasi $n-$ heksana : etil asetat $(3: 1,5 ; v / v)$ sebagai fase gerak dengan volume penotolan $20 \mu \mathrm{L}$. 


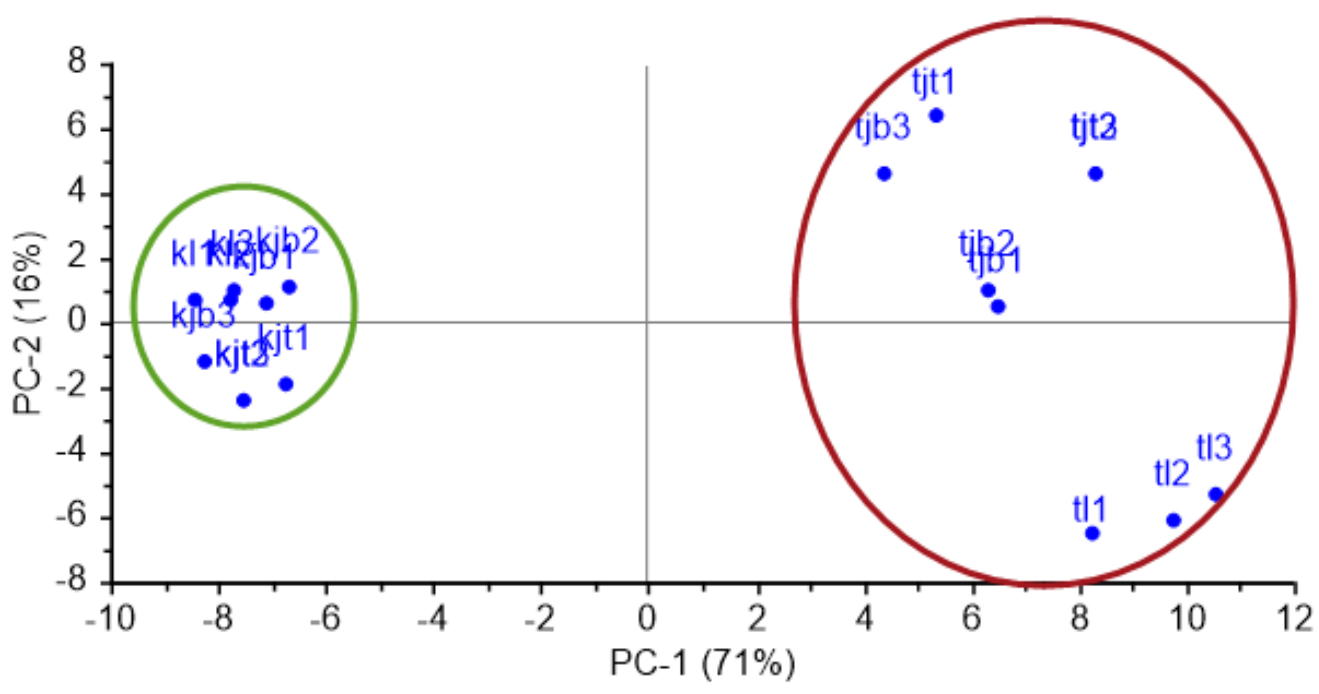

Gambar 4. Plot skor PCA ekstrak baku temu hitam (magenta) dan kunyit (hijau).

PCA mampu membedakan antara ekstrak temu hitam murni, ekstrak kunyit murni, dan sampel (Gambar 4) dengan nilai score PC-1 dan PC-2 berturut-turut adalah 49\% dan 18\%. Kemudian dilakukan validasi metode PCA dari baku temu hitam, kunyit, dan sampel dengan menggunakan metode cross validation. Nilai eigen value PC 1 terhadap PC 2 yaitu 158484,81; dimana hasil validasi dinyatakan valid karena pada persyaratan validasi eigen value yaitu nilai harus lebih dari 1. Adulterasi kunyit terdeteksi pada dua sampel, sampel 1 (sa) dan 2 (sb), dimana diduga adulterannya mirip dengan pola ekstrak kunyit. Sampel pertama (sa) dan sampel kedua (sb) membentuk klaster tersendiri dan berada dekat dengan klaster kunyit dan klaster temu hitam sehingga patut diduga sampel sa dan sb mengandung adulteran kunyit. Sedangkan sampel produk 3 (sc), membentuk klaster pada kuadran tersendiri yang berbeda dengan kuadran dari sa dan sb. Sehingga patut diduga pada sampel produk ketiga (sc) ini tidak mengandung temu hitam dan kunyit. 
Hasil ini memberikan bukti bahwa teknik analisis sidik jari dengan KLT video densitometri efisien dalam mendeteksi keaslian dari sediaan jamu temu hitam. Dengan demikian, metode ini dapat dianggap sebagai metode yang cepat, efektif dan dapat diandalkan untuk mendeteksi pemalsuan dalam sediaan jamu temu hitam.

\section{Kesimpulan}

Analisis sidik jari dengan KLT video densitometri adalah valid dan mampu mendeteksi keaslian dari sediaan jamu temu hitam dengan nilai eigen value sebesar 158484,81.

\section{Ucapan Terima Kasih}

Tim peneliti mengucapkan terima kasih atas pendanaan penelitian ini melalui Riset Internal STFB Bandung Tahun 2018.

\section{Daftar Pustaka}

Angel, G.R., Vimala, B., Nambisan, B. 2012. Phenolic content and antioxidant activity in five underutilized starchy Curcuma species. International Journal of Pharmacognosy and Phytochemical Research, 4(2):6973.

Ashraf, K., Mujeeb, M., Ahmad, A., Amir, M., Mallick, M.N., Sharma, D. 2012. Validated HPTLC analysis method for quantification of variability in content of curcumin in Curcuma longa L (turmeric) collected from different geographical region of India. 2012. Asian Pacific Journal of Tropical Biomedicine, 2(2):S584-S588.

Asnawi, A., Febrina, E., Dinata, D.I., Fazrina, F.N. 2017. Penetapan kadar pseudoefedrin $\mathrm{HCl}$ dan loratadin dalam kombinasi sediaan kapsul menggunakan metode KLT video densitometry. Jurnal Farmasi Galenika, 4(3):98-106.

Booker, A., Frommenwiler, D., Johnston, D., Umealajekwu, C., Reich, E., Heinrich, M. 2014. Chemical variability along the value chains of turmeric (Curcuma longa): a comparison of nuclear magnetic resonance spectroscopy and high performance thin layer chromatography. Journal of Ethnopharmacology, 152(2):292301.

Dalimartha, S. 2007. Atlas Tumbuhan Obat Indonesia. Jilid 3. Depok: Puspa Swara.

Djauharia, E., Sufiani, S. 2007. Observasi keragaan tanaman temu hitam (Curcuma aeruginosa Roxb.) pada berbagai jarak tanam. Warta Tumbuhan Obat Indonesia, 7:2123.

Hess, A.V.I. 2007. Digitally-enhanced thin-layer chromatography: an inexpensive, new technique for qualitative and quantitative analysis. Journal of Chemical Education, 84(5):842-847.

Jayaprakasha, G.K., Jaganmohan, R.L., Sakariah, K.K. 2002. An improved 
HPLC method for the determination of curcumin, demethoxycurcumin and bisdemethoxycurcumin. Journal of Agricultural and Food Chemistry, 50(13):3668-3672.

Muttaqin, F.Z., Yuliantini, A., Fitriawati, A., Asnawi, A. 2017. Penetapan kadar senyawa metampiron dan diazepam dalam sediaan kombinasi obat menggunakan metode KLT video densitometry. Pharmacy: Jurnal Farmasi Indonesia, 13(02):127-136.

Nasrullah, I., Murhandini, S., Rahayu, W.P. 2010. Phytochemical study from Curcuma aeruginosa Roxb. rhizome for standardizing traditional medicinal extract. Journal of International Environmental Application \& Science, 5(5):748-750.

Nurcholis, W., Khumaida, N., Syukur, M., Bintang, M., Ardyani, I.D.A.A.C. 2015. Phytochemical screening, antioxidant and cytotoxic activities in extracts of different rhizome parts from Curcuma aeruginosa Roxb. International Journal of Research in Ayurveda and Pharmacy, 6:634-637.

Pothitirat, W., Gritsanapan, W. 2005. Quantitative analysis of curcumin, demethoxycurcumin and bisdemethoxycurcumin in the crude curcuminoid extract from Curcuma longa in Thailand by TLCdensitometry. Mahidol University Journal of Pharmaceutical Sciences, 32(1-2):23-30.

Reanmongkol, W., Subhadhirasakul, S., Khaisombat, N., Fuengnawakit, P.,
Jantasila, S., Khamjun, A. 2006. Investigation the antinociceptive, antipyretic and anti-inflammatory activities of Curcuma aeruginosa Roxb. extract in experimental animals. Songklanakarin Journal of Science and Technology, 28:9991008.

Rohman, A., Devi, Sudjadi, Ramadhani, D., Nugroho, A. 2015. Analysis of Curcumin in Curcuma longa and Curcuma xanthorriza using FTIR spectroscopy and chemometrics. Research Journal of Medicinal Plants, 9:179-186.

Simoh, S. dan Zainal, A. 2015. Chemical profiling of Curcuma aeruginosa Roxb. rhizome using different techniques of solvent extraction, Asian Pacific Journal of Tropical Biomedicine, 5(5):412-417.

Srivastava, S., Chitranshi, N., Srivastava, S., Dan, M., Rawat, A.K.S., Pushpangadan, P. 2006. Pharmacognostic evaluation of Curcuma aeruginosa Roxb. Natural Product Sciences, 12(3):162-165. 